DOI: 110.2478/ausp-2018-0018

\title{
Representation of Immigrants in British and American Newspapers
}

\author{
Gabriela CHEFNEUX \\ Transilvania University of Braşov (Romania) \\ Department of Literature and Cultural Studies \\ gabriela.chefneux@unitbv.ro
}

\begin{abstract}
One of the major functions newspapers have is that of (re)presenting reality for their readers and thus explain events and promote specific values; newspapers are multimodal texts, which resort both to language and images to convey their message. The paper analyses a British and a North American newspaper article and has two aims. Firstly, to investigate the strategies used by journalists to represent immigrants in a positive way and, secondly, to draw a comparative analysis between the articles in terms of these strategies. The theoretical part defines the concept of racism and the ways in which it is nowadays expressed and lists some of the strategies that are frequently used to present immigrants (such as topic, referential strategies, intensifying, extensivization, victimization, personalization, voices heard, argumentation, etc.) with the use of pictures. The second part identifies strategies used in these two articles. The conclusions present a comparison between them in terms of similarities (values upheld, type of argumentation) and differences (intensification and nomination strategies, quotation patterns).
\end{abstract}

Keywords: immigrants, racism, linguistic strategies, pictures.

\section{Introduction}

Newspapers have a social, political, and educational role. By being exposed to news, people try to understand and explain how events reported in the media relate to society as a whole and how these events can be interpreted. News is the report or recontextualization of an event since the treatment of any topic always depends on the way in which it is framed and on whose perspectives and opinions are presented. News, therefore, is not an objective representation of facts but a cultural construct that encodes fixed values; news is socially and culturally determined, being described as the partial, ideologically framed report of the event (Caldas Coulthard 2003: 273-274). As such, newspapers promote social and moral values, which they legitimate (Chibnall 1977). 
Newspapers are multimodal ways of communication as they also convey their messages by means of visual elements, such as font size and photographs, whose colours, focus, and depth are significant (Kress-van Leeuwen 1996).

\section{Theoretical framework}

\subsection{Immigration}

According to Wise, migration is the population movement "occasioned by the lack of proper living and working conditions, or life-threatening political and social conditions" (Wise 2010: 174). However, today, migration is defined as "a conflation of forced and economic migration" (Philo-Briant-Donald 2013: 3). On the one hand, immigrants are considered as a burden for the host country because they are said to take the jobs of the host country's citizens, to increase the criminality rate, to be unable to adapt. On the other hand, they are believed to represent an advantage for the economy of the host country as they do the hard jobs for less money, do the jobs that the citizens of the host country do not want, pay taxes and, by bringing their own traditions, customs, mentalities, and arts, they also make a cultural contribution. Moreover, they send money home, thus increasing the living standard in the poorer countries while politically they strengthen the ties between the home and the host countries. These two contradictory perspectives are reflected in mass media, which have portrayed immigrants in two extreme ways - as a threat or opportunity.

\subsection{Racism}

Racism is defined as a "system of ethnic or racial dominance [...] or systematic power abuse" over other kinds of groups, such as ethnic minorities, immigrants, or refugees (Van Dijk 2011: 15). It is also described as the illegitimate exercise of power resulting in social inequality, which involves the exclusive or preferential access to, or control over, scarce social resources, such as residence, housing, employment, health care, income, status, knowledge, and respect (van Dijk 2008). The system of ethnic domination has two major dimensions: social and cognitive. The former consists of everyday social practices of discrimination - exclusion from or being provided with limited access to social resources or human rights; the latter consists of the ethnic beliefs, stereotypes, prejudices, and ideologies which justify these discriminatory practices; thus, newspapers represent one way in which the cognitive dimension is achieved (van Dijk 2008). In Europe, since the 80s, openly expressed racism has become "politically incorrect", but it has found other ways of expression: the negative views of socially oppressed 
groups are presented as reasonable or justified based on objective facts coming from the speakers' own experience, who are thus protected against the charge of being prejudiced or racist (Barker 1981). There are heated debates within the academic literature as to what precisely counts as racist (van den Berg-HoutkoopSteenstra-Wetherell 2003), and it has been claimed that what can be interpreted as racism is actually political or ideological conservatism (Sniderman-Tetlock 1986). Conversely, the denial of the existence of racism and prejudice has been interpreted as indicating racist views.

\subsection{Linguistic strategies}

Wodak (2009: 40) defines strategy as "a (more or less accurate and more or less intentional) plan of practices, including discursive practices, adopted to achieve a particular social, political, psychological, or linguistic goal”, to support a particular view of an event, situation, or group of people. The list below includes some of the most frequently used linguistic strategies that are used to present immigrants in newspapers in either a positive or a negative way:

- topic or subject of the article (van Dijk 1991);

- lexicalization, terms that are frequently used in order to influence the readers to adopt a particular attitude (van Dijk 2000);

- categorization, labels used for identification;

- roles assigned, the position of the person described; migrants are usually passive, being presented as a threat or burden;

- perspectivation, the means by which speakers express their involvement in discourse and the point of view in reporting, describing, narrating, or quoting (Wodak 2009);

- referential or nomination strategies, the ways in which social actors are constructed and represented; they include the use of metaphors, metonymies, and synecdoches (Reisigl-Wodak 2001);

- predicational strategies, evaluative attributions of negative and positive traits in the linguistic form of implicit or explicit predicates; predicational strategies cannot be neatly separated from nomination ones (Reisigl-Wodak 2001);

- intensifying and mitigation strategies, which qualify and modify the epistemic status (Wodak 2009: 20);

- quotation patterns, the voices that are or are not heard in a text (van Dijk 2009);

- argumentation strategies, which can resort to ethos (the arguer presenting him/herself as a particular type of person), pathos or emotion (aiming to influence the audiences' emotions), and logos (appeals to reason);

- topoi, parts of the explicit or inferable premise in argumentation; several kinds of topoi have been identified such as advantage/usefulness, danger/threat, 
definition/name-interpretation, burdening/weighing down, law/right, culture, abuse, and authority (Reisigl-Wodak 2001: 75);

- personalization/impersonalization, emphasis or lack of emphasis on particular features of individuals (Khosravinik 2010: 7);

- metaphors, used to make abstract or complex meanings more concrete and understandable (van Dijk 2009);

- victimization, focus on an individual's fears or struggles presented in such a way as to arouse the readers' sympathy (Koshravinik 2010: 20);

- extensivization, the detailed presentation of horrible or tragic events in which an individual is involved (Koshravinik 2010: 22).

The British and the American articles are analysed below based on the following strategies: topic, lexicalization, nomination strategies, quotation patterns, individualization, victimization, and extensivization (the last one being opposed to detailed presentations of people and their situation). The aim is to identify similarities and differences between the two articles; this analysis represents a starting point which could be further expanded into a content analysis with a view to generalizing positive ways of representing immigrants in British and North American newspapers.

\section{Article analysis}

The two articles studied below are taken from the on-line editions of The Independent and The Washington Post. The British article is entitled Finsbury Park mosque terror attack: Victim Makram Ali's family describe trauma of losing "peaceful" grandfather, written by Lizzie Dearden and uploaded on 2 February 2018. The second article is entitled I can't take that place. An Arizona family struggles with a mother's deportation, written by Samantha Schmidt and uploaded on 2 February 2017. These texts were selected because they deal with immigrants, the journalists adopt a similar position, and were published at a rather short interval one after the other.

\subsection{Analysis of the British article}

The topic of the article is the terrorist attack mounted on the Muslim community in Finsburk Park by Darren Osborn. Actually, this article is part of a longer series which describes the event, the trial, the reaction of the victim's family, Muslim community, and officials.

Makram Ali went to pray at the mosque and, before reaching it, he fell down in the street; the other community members gathered around him to help; at this moment Darren Osborne drove into the crowd around Makram Ali, killing him 
and injuring several other people. The journalist's position is sympathetic to the victim and to the Muslim community.

In terms of referential strategies, Makram Ali is described as a family man husband, father of six, and grandfather of two: "The beloved 'family man' lived with his wife nearby and had six children and two grandchildren" (Dearden 2018). The family "has tragically lost a husband, father and grandfather" (Dearden 2018). He is a "peaceful grandfather", a "quiet and gentle man, who was loved and respected by all those he knew", a "peaceful and simple man", who "had no bad thoughts for anyone", a "sincere and warm person", "always full of laughter and immense love for his family", a man who "lived his life without enemies" (Dearden 2018).

The effects of Makram Ali's death on his family are presented in detail: one of his daughters is "struggling not to fall apart" (Dearden 2018) under the weight of her grief, his wife is too scared to leave the house, and one of his grandchildren keeps asking about his grandfather as he cannot understand why he is missing.

He is presented as a victim - in the headline, the first word used to describe him is victim and only then comes his name, "Victim Makram Ali" -, and his death is described in strong words - he "died of "catastrophic' internal injuries caused by being run over" (Dearden 2018). The article provides a gradual perspective on the murder - moving from a narrower perspective (family and community) to a wider one (government).

The terrorist attack has affected the Muslim community in many ways: the people hurt in the attack are depicted as innocent victims, helpless people, who have no bad intentions. They are described in detail: "the victims injured by Mr. Osborne included men and women of all ages, a group of deaf people and a man who was knocked out of his wheelchair" (Dearden 2018). The Muslim community is affected not only physically but also emotionally: some are severely wounded "sustaining life-changing injuries" -, others cannot overcome the memory - they have recurring flashbacks, nightmares and trauma, which leave them "unable to sleep and in constant fear", and a few victims have lost their jobs as a result of "physical and mental toll" (Dearden 2018). They are afraid for themselves and their children, do not want to leave their house, and fear attacks because of the mere reason of being Muslims. The ordeal continues during the trial too, described as traumatic, "grueling", and bringing back painful memories.

The opposition of victim vs aggressor is strongly emphasized in the article in several ways: the victims are peaceful, kind, honest, and compassionate, while the aggressor is driven by hate and does not assume responsibility for his crime. This contrast is stressed by the words of one of the Muslim victims who was hit by the van while trying to help Makram Ali; Sharij Xamza states: "it was human to help another human - and then you too become a victim of attack" (Dearden 2018).

However, the community is strong and supportive of their members: they do not yield to the impulse of punishing the attacker themselves but defer him to 
justice, are determined to continue living a normal life, fighting victimization and violence, and offering to the police "tremendous support and understanding" (Dearden 2018).

Another perspective offered is that of the British authorities: the police, the Court, and the Home Secretary, who speak on behalf of the British government; their attitude indicates compassion for the victims and determination to see justice served. The article is a combination of facts and quotations, leaving the impression of utter objectivity, but actually they are all supporting the Muslim community.

The voice of Makram Ali's daughter is often heard as she speaks about her father. Other sources quoted in the newspapers are: Sharij Xamza, one of the victims, lawyer Dushal Mehta, who praises the Muslim community and describes their reaction to the attack, Justice Cheema-Grubb, who praises the victim and criticizes the terrorist act, Commander Dean Haydon, Head of the Department of Counter Terrorism in the Metropolitan Police, who expresses his appreciation for the support received during the investigation from the family and the community, and finally Amber Rudd, Home Secretary, who states the government will protect the British way of life against terrorism.

The British officials' quotes include modals and vague words such as must or whatever. Commander Dean Haydon states: "I would like to pay tribute to Mr. Ali's family and the local community in Finsbury Park, for their tremendous support and understanding with our investigation during what must have been an extremely difficult time for them" (Dearden 2018), where the use of must may indicate logical deduction. Similarly, the Home Secretary states the Government's position, which will be of "combating all forms of terrorism, whatever the underlying motivation" (Dearden 2018) - an adverbial clause of concession, which mitigates the cause of this particular attack.

The type of argumentation is a combination of appeals to feeling as the situation is presented from the point of view of the family and Muslim community and appeals to logic as the article provides facts and quotations. The values upheld in this article are love (for the family), peacefulness, legality, moderation, and cooperation for the Muslim community, while legality, cooperation, order, constructiveness, openness, honesty, rationality, impartiality, and fairness for the authorities. They are opposed to the attacker's values which are linked to illegality, extremism, dogmatism, chaos, intolerance, destructiveness, and irrationality.

The pictures ${ }^{1}$ related to the family, the community, and British official institutions support and enhance the message of the article. The first picture is of the victim's family making a statement outside the court. The colours are dark, suggesting grief, and the man and two women look downwards or sideways, not

1 Available at: http://www.independent.co.uk/news/uk/crime/finsbury-park-mosque-attackvictim-makram-ali-terror-grandfather-loss-trauma-osborne-darren-terror-a8191731.html (last accessed on 28 September 2018). 
into the readers' eyes, which indicates pain. The next picture is of the police on the night of the attack, and it is part of a set of 14 pictures which can be read as the visual narrative of the attack; others present the Muslim community's reaction a young man with raised hands, which can signify that what he sees is painful and difficult to understand, pictures of the Muslim community praying on the sidewalk, Londoners of other ethnicities, all deeply affected and shocked by the attack. The last picture in the article is of Makram Ali, who appears to be quiet and peaceful, as his family and friends describe him. Like the other members of his family, he does not look forward but sideways, which may indicate lack of connection with the readers. The colours are soft and restrained.

In conclusion, the article uses as main strategies individualization (as Makram Ali is presented in detail), victimization (the family's and the community's struggle), perspectivization (family, community, and British officials - all in favour of the Muslim community), intensification (the effects of the attack on the family and community are amply depicted), and extensivation (the family's and community's tragic losses). The type of argumentation is a mixture of feeling and reason.

\subsection{Analysis of the US article}

The topic of the article is the deportation of Guadalupe Garcia de Rayos and its effects on her family. The referential strategies indicate that Guadalupe Garcia de Rayos is first of all a mother and a wife. It is worth noticing that the indefinite article $a n$ is used in the headline and in the body of the article: "An Arizona family", "a mother's deportation" (Schmidt 2017), which suggests that this is a case similar to many others.

Guadalupe Garcia de Rayos is presented as a caring wife and loving mother whose main concern is to provide a good home to her family. She is sometimes referred to as "Lupita" by her husband or very frequently as "mother" by her children. She is a humble, hard-working woman, deeply religious, honest, and selfless - she works as a volunteer at church carnivals. The last part of the article presents a different side of Garcia de Rayos, namely no longer through the eyes of her family but as an independent individual; interviewed after her deportation to Mexico, she states that she feels sad when she thinks of her family being without her, but, on the other hand, she would not have changed anything. She declares that given the choice of missing an appointment with the legal authorities or attending it and run the risk of being deported, she decided to go and was thus deported: she says "it was the right thing to do, even if it had consequences" (Schmidt 2017). She assumes responsibility for her actions and has the strength to reconsider her position from a wider perspective, talking about herself as one of the many Mexicans in the same situation. "I knew they could have arrested me. But this was as much for me as it was for everyone else" (Schmidt 2017). 
Garcia de Rayos's husband and children are presented as deeply affected by her deportation: her husband is afraid that he cannot take proper care of the children and cannot take his wife's place in the relation with their daughter, a 14-year-old girl, who at this age needs her mother near her: "He worries most about Jacqueline, barely on the cusp of womanhood, a time in her life when she most needs the advice of a mother" (Schmidt 2017). Angel, the 16-year-old son, admits he cannot focus at school sometimes, while the daughter tries to be brave and hide her sorrow in public, but when she is alone she cries and completely loses control. The lexical field suggests sorrow and worry from its very beginning, as indicated by words such as silent and empty: "The house was nearly silent as the father stood in the empty kitchen" (Schmidt 2017).

The family's position is presented as opposed to the official one. The children grieve for their mother and have to restructure their lives now that she is no longer with them, while Garcia de Rayos is officially considered a criminal. "People like their mother apparently weren't welcome here. As a country reevaluated its position on undocumented immigrants, they would have to reevaluate a life without the one who mattered most to them" (Schmidt 2017).

The same opposition is further discussed in the article - Garcia de Rayos's case has become famous, and supporters of harsh illegal immigration law consider that her crime, that of having forged a false social security card, should be punished; moreover, they state that Garcia de Rayos has been turned into a "political martyr". Again, the official position is contrasted to that of the family: "[b]ut to her husband and children, Garcia de Rayos is no criminal. She made up her Social Security number to help provide for the kids, her husband says, a choice many undocumented immigrants resort to across the country" (Schmidt 2017). The linguistic structures used are antonymic, as indicated by the parallel structures and the use of but.

There are three levels in the article - the first is the family, the second the Mexican community, where many members face very similar situation, and the third one is related to the US immigration laws. The Mexican community is presented as undergoing a difficult period, as they are afraid of the increasingly harsh immigration rules and of the way these are enforced; the adjective used to describe their situation is "re-traumatizing", indicating continuous suffering. They resort to the community for support and attend meetings on human rights in an attempt to identify ways to protect themselves.

The third level is the political one; the journalist does not openly criticize US immigration rules and President Trump's most recent regulations, but the framing and the quotations do. Thus, the article states that the US immigration rules were unevenly enforced, which "alienated both the country's citizens and the customs officers" (Schmidt 2017) and resulted in desperate situations such as the one presented in the article. The journalist supports a more individual 
enforcement of law against undocumented immigrants; the ones "living in the country productively" (Schmidt 2017) should benefit from a different treatment. A more open critique is made by the comparison between Joe Arpaio, the former sheriff of Maricopa County, an officer famous for the strictness of his raids, and President Trump, who entertains a similar attitude and who is called "Arpaio in the White House" (Schmidt 2017). The SB 1070 law, which states that it is the police's responsibility to establish the status of the arrested person, is described as "hotly contested", while Garcia de Rayos is described as "a nonviolent offender" who forged the papers to help to support her family.

All the sources quoted in the article represent the Mexican perspective. The family members are very often quoted directly, thus making the readers understand and sympathize with them. Other voices heard in the article are those of Francisca Porchas and Natally Cruz, leaders of a Phoenix group that fights for immigrants' rights. They comment on the opposition between the personal and official positions: "The sad part about it [undocumented immigrants being advised how to fight for their rights] is that we're going to find out how it works but lose people in the process" (Schmidt 2017).

The arguments brought in this article mainly appeal to feelings as they describe the difficulties undergone by the entire family and by the community but also to reason as the story seems to be told objectively. The values upheld in the article are tolerance, compassion, and family relations. One of the main strategies is extensivization as the effects of the mother's absence on the family are presented in detail and intensification, as indicated by the use of words such as "traumatizing", "high level of anxiety", "lose people", and "we're destroyed" (Schmidt 2017).

The pictures ${ }^{2}$ suggest the idea that the family is trying to cope with their new life but apparently cannot. The first picture in the article is of the incomplete family - the father and the two children under a painting of the Virgin Mary. The father is sitting between the two children, with his arms around his daughter's shoulder, suggesting a protective stance. Another picture is of the family with the mother in the middle, an indication of her important part in the family - she holds the child, and the husband is very close to her; above their head is a starred sky, which indicates that the family is deeply religious. The last but one photo in the article shifts the emphasis from the family to the community - the photo presents a meeting of the Mexican community discussing ways of protecting themselves against immigration rules. Most of the people in the picture are with the back towards the reader, which may be interpreted as a severed connection with the town where they live.

2 Available at: https://www. washingtonpost. com/national/i-cant-take-that-place-anarizona-family-struggles-with-a-mothers-deportation/2017/02/27/e0b0d0de-fa0e-11e6-bf01d47f8cf9b643_story.html?utm_term=. a17da5a02534 (last accessed on 28 September 2018). 
The main strategies used in this article are intensification (as indicated by the adjectives used to present the effects of Garcia de Rayos's deportation on her family), extensivization (the detailed presentation of these effects), and victimization (the unjust way Garcia de Rayos is treated by US authorities).

\section{Conclusions}

Both articles offer a positive representation of immigrants as they describe the hardships these communities go through: the British article depicts a terrorist attack against the Muslims, while the US article presents the consequences of enforcing the US recent immigration law on the Mexican community. Both articles provide a very detailed account of the situation, with intensification strategies used more frequently in the UK article.

The nomination strategies are slightly different - more official in the British newspaper and less official in the US one. In both articles, the victims are presented as having important family roles - parent, spouse, grandfather -, and all the characters are presented as people living very similar lives to that of the readers so that the readers can identify with them easily.

In both articles, the movement is from the individual perspective, which is described in the largest part of the article, to the community, and then to the official one. The individual and the official levels are presented as being in contradiction in the US article, which is also critical of the immigrants' current situation.

The quotation pattern is different as more sources are quoted in the British newspaper. The journalists' positions are distinct - in the British article, the official point of view is fully supported, while in the US it is admitted that laws should be enforced but taking into account individual situations and adopting a more humane approach. Both articles represent a combination of appeals to feeling and reason, with a stronger sentimental tendency in the US one, therefore a slightly different type of argumentation.

The comparative analysis of the pictures indicates that the message of both articles is strengthened by the use of photographs. The ones in the UK newspaper point to the individual features of the Muslim community in terms of clothes and traditions - one of the pictures is of Muslims praying in the street; generally, the colours are dark. The photographs in the US article suggest more regular activities and things: a family's house, objects, and routines. The colours are bright and the people are sometimes smiling, which suggests a more humane and compassionate attitude.

Overall, the US article adopts a more personal approach, appeals more to feelings, and has a more critical attitude of the authorities. 


\section{References}

Barker, Martin. 1981. The New Racism. London: Junction Books.

Caldas-Coulthard, Carmen Rosa. 2003. Cross-cultural representation of 'otherness' in media discourse. In Weiss, Gilbert and Wodak, Ruth (eds), Critical Discourse Analysis Theory and Interdisciplinarity, 272-296. Basingstoke: Palgrave Macmillan.

Chibnall, Steve. 1977. Law and Order News. London: Tavistock.

Dearden, Lizzie. 2018. Finsbury Park mosque attack: Victim Makram Ali's family describe trauma of losing 'peaceful grandfather.

http://www.independent.co.uk/news/uk/crime/finsbury-park-mosqueattack-victim-makram-ali-terror-grandfather-loss-trauma-osborne-darrenterror-a8191731.html. (Last accessed: 29 January 2018).

Delgado, Wise Raùl. 2010. The migration-development nexus: A Marxist class perspective. In Henry Veltmeyer (ed.), Imperialism, Crisis and Class Struggle: The Enduring Verities and Contemporary Face of Capitalism. Essays in Honour of James Petras, 171-190. Leiden and Boston: Brill.

Khosravinik, Majid. 2010. The representation of refugees, asylum seekers and immigrants in British newspapers: A critical discourse analysis. Journal of Language and Politics 9(1): 15-26.

Kress, Gunther-Theo van Leeuwen. 1996. Reading Images: The Grammar of Visual Design. London: Psychology Press.

Philo, Greg-Emma Briant-Pauline Donald. 2013. Bad News for Refugee. London: Pluto Press.

Reisigl, Martin-Ruth Wodak. 2001. Discourse and Discrimination: Rhetorics of Racism and Anti-Semitism. London-New York: Routledge.

Schmidt, Samantha. 2017. I Can't Take That Place. An Arizona Family Struggles with a Mother's Deportation. https://www. washingtonpost. com/ national/i-cant-take-that-place-an-arizona-family-struggles-with-a-mothersdeportation/2017/02/27/e0b0dode-fa0e-11e6-bfo1-d47f8cf9b643_story. html?utm_term=.a17da5a02534. (Last accessed: 2 February 2018).

Sniderman, M. Paul-Philip E. Tetlock. 1986. Symbolic racism: Problems of motive attribution in political analysis. Journal of Social Issues 42: 129-150.

van den Berg, Harry-Hanneke Houtkoop-Steenstra-Margaret Wetherell (eds). 2003. Analyzing Race Talk: Multidisciplinary Approaches to the Interview. Cambridge: Cambridge University Press.

van Dijk, Teun, A. 1991. Racism and the Press. London: Routledge. 2008. The Role of the Press in the Reproduction of Racism.

http://www. springer.com/978-3-7091-0949-6. (Last accessed: 5 February 2018). 
2000. Parliamentary debates. In Wodak, Ruth and van Dijk, Teun A. (eds), Racism at the Top: Parliamentary Discourses on Ethnic Issues in Six European States. Austria: Drava Verlag, 45-78.

2011. Discourse and Racism. Some Conclusions of 30 Years of Research. http://www.discourses.org/UnpublishedArticles/Discourse \% 20and \% 20 Racism.pdf (Last accessed: 2 March 2018).

Wodak, Ruth. 2009. The Discourse of Politics in Action: Politics as Usual. London: Palgrave Macmillan. 